sufficient time to correct the anaemia in the pre-assessment before surgery. Therefore, we propose that at the point when a GP decides that a patient is likely to need arthroplasty, tests are done to identify anaemia and where necessary treat with haematinics before the initial orthopaedic consultation.

\section{Hari Boralessa}

Consultant Transfusion Medicine, National Blood Service, Crescent Drive, Brentwood, Essex, CM15 8DP.

E-mail: hari.boralessa@nhsbt.nhs.uk

DOI: 10.3399/bjgp08X319512

\section{Death certification post Shipman}

A decade after Shipman's arrest ${ }^{1}$ and 4 years since the Shipman Inquiry report into death certification was published, ${ }^{2}$ the key proposals have been scarcely debated, let alone any having led to serious action. We believe this failure may be due to the tenor of the inquiry's proposals which saw death as a potentially criminal act to be forensically investigated, rather than an opportunity for proper certification and potential learning. ${ }^{3}$

The present impasse leaves us worse off than a decade ago, as no one can be satisfied with the current system which is known to be seriously flawed, yet there is clear doubt as to how to proceed. Indeed, locally introduced variations of certification practice, especially regarding cremation, probably abound.

We consider that the Royal College of General Practitioners is best placed to reopen the debate publicly about death certification. The suggestion of 'pilot schemes during 2008'3 should be actively pursued and College members and others encouraged to participate.

Each death is a significant event and many have lessons for future practice. In our experience these are essential learning opportunities that ought to be part of each doctor's revalidation portfolio. ${ }^{3}$ For those doctors and teams who are struggling to perform adequately, it is also our experience that a search through the records of the patients who have died can reveal both clinical and systems problems far more quickly than anything else.

'A retrospective search for avoidable factors in individual deaths is perhaps the most stringent form of self-criticism available to any clinical team.' ${ }^{4}$

\section{John Holden}

Garswood Surgery, Garswood, St Helens, WN4 OXD. E-mail: john@holdens.org.uk

\section{Steve Cox}

The Spinney Medical Centre, Whittle Street, St Helens, Merseyside, WA10 3EB.

\section{REFERENCES}

1. Baker R. Making haste slowly: the response to the Shipman Inquiry? Br J Gen Pract 2008; 58(550): 307-308.

2. The Shipman Inquiry. Fifth Report. Safeguarding patients : lessons from the past - proposals for the future. The Shipman Inquiry, 2004. http://www theshipman-inquiry.org.uk/fifthreport.asp (accessed 12 Jun 2008).

3. Holden J, O'Donnell S, Brindley J, Miles L. Analysis of 1263 deaths in four general practices. Br J Gen Pract 1998; 48(432): 1409-1412.

4. Hart JT, Humphreys C. Be your own coroner: an audit of 500 consecutive deaths in general practice. BMJ 1987; 294(6576): 871-874.

DOI: 10.3399/bjgp08X319521

\section{'Home Office syndrome'}

We wish to offer a name for a syndrome which will be familiar to those working with refugees and asylum seekers. While asylum seekers are awaiting a Home Office decision on their asylum claim, they often give no attention to their other needs; in particular, their health needs. This is because they often fear that they will be killed or tortured if they are returned to the countries from which they came.

The health and health behaviours of asylum seekers are strongly influenced by their social circumstances - starting with the events that have happened in the countries they have come from, the stress of separation from their family and everything that is familiar, and the difficulties they face here. Once in the UK, taking care of their health, or bothering to take tablets for conditions, such as high blood pressure or diabetes, seems unimportant compared to the immediate problems of survival. Health problems take second place to the progress of their asylum case - people will miss important appointments with their GP or hospital specialist to see their solicitor.

The 'Home Office syndrome' is perhaps a specific example of Maslow's hierarchy of needs. While the individual is dealing with what he perceives to be a threat to his life, all other matters, including health care, are put on hold.

The delays in deciding asylum status have been long and may still last months. As a result, the 'Home Office syndrome' is bad for the health of asylum seekers who may wait long periods before they seek appropriate help for their health needs. Other examples of policies that damage the health of asylum seekers are those that prevent legal employment, ${ }^{1}$ and the refusal of secondary health care for 'failed' asylum seekers. The last policy has recently been judged illegal in the High Court. ${ }^{2}$

\section{Gervase Vernon}

GP and medico-legal report writer, Medical Foundation for the Care of Victims of Torture, London, N7 7JW.

\section{Dave Ridley}

Practice Nurse, Cape Hill Medical Centre, Smethwick, West Midlands.

\section{Dineo Lesetedi}

Practice Nurse, The Meridian Practice, Coventry.

\section{REFERENCES}

1. Vernon G, Feldman R. Refugees in primary care: from looking after to working together.

http://www.networks.nhs.uk/uploads/06/06/refugees in_primary_care.doc (accessed 12 Jul 2008).

2. Department of Health. Failed asylum seekers and ordinary residence.

http://www.dh.gov.uk/en/Publicationsandstatistics/Le ttersandcirculars/Dearcolleagueletters/DH_084479. (accessed 12 Jul 2008)

DOI: 10.3399/bjgp08X319530 